DOI: https://doi.org/10.24127/ajpm.v9i4.3065

\title{
THE REWARD OF WORSHIP IN RAMADHAN DURING COVID-19 PANDEMIC: A MATHEMATICAL ANALYSIS
}

\author{
Akhsanul In'am ${ }^{1 *}$, Maya Rayungsari² \\ 1*Pendidikan Matematika, Universitas Muhammadiyah Malang, Indonesia \\ ${ }^{2}$ Pendidikan Matematika, Universitas PGRI Wiranegara, Indonesia \\ *Corresponding author. Universitas Muhammadiyah Malang, Kota Malang, Indonesia \\ E-mail: $\quad$ akhsanul@umm.ac.id ${ }^{1)}$ \\ maya.rayungsari@gmail.com $^{21}$
}

Received 29 August 2020; Received in revised form 04 December 2020; Accepted 19 December 2020

\begin{abstract}
This research aims at analyzing the rewards obtained from carrying out worship in Ramadhan during the Covid-19 Pandemic Period. The research approach applied was qualitative with the type of library research. The objects of the research were prayer, reading Al Qur'an and Al-Hadith. The Covid-19 pandemic period, according to the regulation issued by the government of Indonesia in the form of social distancing, gave great impacts on the implementation of worship during Ramadhan. The data were analyzed based on the stipulations and guidelines of implementing the worship, especially during Ramadhan, which had been analyzed using mathematical calculations. The research results showed that the reward of implementing worship during the Covid-19 pandemic period was tremendous either in quantitative or qualitative calculations. In addition, it focused on the quality, so that the results of this research can be utilized as a basis for improving the quality of worship.
\end{abstract}

Keywords: mathematics; reading Al Qur'an; Al-Hadith; worship

\begin{abstract}
Abstrak
Penelitian ini bertujuan untuk menganalisis manfaat yang diperoleh dari melaksanakan ibadah di bulan Ramadhan selama Periode Pandemi Covid-19. Pendekatan penelitian yang digunakan adalah kualitatif dengan jenis penelitian kepustakaan. Objek penelitiannya adalah shalat, membaca Al-Qur'an dan AlHadits. Masa pandemi Covid-19, menurut aturan yang dikeluarkan pemerintah Indonesia berupa social distancing, berdampak besar pada penyelenggaraan ibadah selama Ramadhan. Data dianalisis berdasarkan ketentuan dan pedoman pelaksanaan ibadah khususnya pada bulan Ramadhan yang dianalisis menggunakan perhitungan matematis. Hasil penelitian menunjukkan bahwa pahala melaksanakan ibadah selama periode pandemi Covid-19 sangat besar baik secara kuantitatif maupun kualitatif. Selain itu juga menitikberatkan pada kualitas, sehingga hasil penelitian ini dapat dimanfaatkan sebagai dasar untuk peningkatan kualitas ibadah.
\end{abstract}

Kata kunci: matematika; bacaan Al Qur'an; Al-Hadits; ibadah

This is an open access article under the Creative Commons Attribution 4.0 International License

\section{INTRODUCTION}

Ramadhan is a special month for Muslims as it is full of blessings and mercy. It is a special month since Muslims possesses a specific ritual by carrying out fasting worship for one month, and in this month it is shown and modelled by the Prophet Muhammad
PBUH to perform Taraweeh prayers each night during the month of Ramadhan (Al Qur'an, 2:185, HR Bukhari \& Muslim). Moreover, various suggestions to do worship, either the one dealing with vertical or horizontal relationships and maintaining health (Cohen \& Kupferschmidt, 2020; 
Kong,2020). The combination of the improvement of the quantity and the quality of the vertical and horizontal relationships may make human beings able to implements guidance's that have been determined.

The implementation of worship in the month of Ramadhan is different from other months because of the promise given by Allah to His people that anyone who performs worship during the month of Ramadhan will get higher reward than in the other months. The worship is not merely related to the vertical relationship with Allah SWT, but also the horizontal relationship, the relation to human beings (Al Qur'an, 2:185, HR Bukhari \& Muslim).

The real differences of worship performed during the month of Ramadhan are among other, seriousness in reading $\mathrm{Al}$ Qur'an done independently or collectively, and in studying the content of Al Qur'an intensively so that it will be beneficial for health (Tumiran, 2018). The implementation of the Taraweeh sunnah prayers only exists during Ramadhan. For those with abilities in carrying out fasting, they should fast each day during the month of Ramadhan. Still, those without such abilities such as those who are senile persons, pregnant women, hard workers, and those who are travelling, they may replace their fasting by giving fidyah or fasting in other months out of Ramadhan.

During Ramadhan, another good habit is giving charity which is done by those who intend to share happiness and have excess assets (Alsharidah, et, al, 2016, Purwatiningsih, et al. 2018, Ali \& Khakwani, (2019). Additionally, this habit increases rapidly during Covid-19 pandemic because there are many members of the society impacted by Covid-19 pandemic, especially those who have low income and lost their income or jobless (Rokhim \& Octaviani, 2019, Saripudin, 2016). The forms of charity are varied, such as giving foods or cash, as one of the efforts to lighten the burden of those getting impacts from the Covid-19 pandemic.

In this pandemic, the government of Indonesia has made rules to reduce the spread of the virus. A large scale social distancing restriction is one of the efforts made by the government to narrow the spread of the virus (Cohen \& Kupferschmidt, 2020). One regulation in the implementation of the large scale social distancing restriction is to work from home and also to perform worship at home (Kong, 2020; Lane et al., 2020; Zaharah \& Kirilova, 2020). This regulation is intended to reduce interactions among people. As a Muslim, we should obey the rules by employing the principle of jurisprudence, dar'ul mafasid muqodamu ala jalbul masolih, which means avoiding damage is more important than taking benefits. It also gives impacts on the implementation of worship such as Friday prayers in the mosques is forbidden during Covid-19 pandemic period.

One of the motivations in doing various activities is to get rewards. This also applies to perform an instruction to worship. Allah gives rewards to anyone who is willing and able to perform various worships in line with the provisions. Those who are ready to pray in the congregation will be given by Allah 27 degrees' reward than those who pray individually. The people who deign to read Al Qur'an will be noted by Allah 10 goodness for each word read. It also prevails for anyone willing to give charity. He will be given multiple rewards, namely 700 times of the value of the rewards given (Al Qur'an, 2:261).

The problem of this study is how much goodness and reward that may be 
acceptable in carrying out worship in Ramadan, especially during the Covid19 pandemic, if it is analyzed mathematically?

\section{METHOD}

A qualitative method with library research type was employed in this research. The object of the research was worship conducted during Ramadhan month and the Covid-19 pandemic. The data were collected from documents such as Al Qur'an and Hadith. The instrument used was by tracing the basis of Al-Quran and Al-Hadith based on the topics being studied.

The data were analyzed by studying worship that may be done in the Ramadhan month from congregational prayers, syuruq prayers, reading $\mathrm{Al}$ Qur'an and implementation of AlHadith. The analysis was made by using postulates from Al Qur'an and Hadiths which is mathematically calculated in order to find the calculation of prayer value in line with the stipulations in $\mathrm{Al}$ Qur'an and Hadiths.

\section{RESULTS AND DISCUSSION}

The Covid-19 pandemic period may give impacts on the togetherness in families to perform worship at home. Ramadhan month this year is really special. Last year some members of the family had activities out of home, such as breaking the fast together, Taraweeh prayer together, doing missionary endeavours in other places. But this year, all activities of all members of the families should be done at home.

The description of the research results began from obligatory worship, and then it was continued with sunnah worship in which the doers would get multiple rewards based on a proposition from Al Qur-an and Al Hadiths.
1. The implementation of compulsory prayers.

Prayers performed alone have different levels with those done in the congregation. During the Covid-19 pandemic period, due to appeals to working from home, and also doing prayer at home, it enables each prayer may be performed in a congregation with all members of the family. The Prophet Mohammad PBUH appreciated those performing congregational prayers as stated that "Congregational prayers outperform praying alone 27 degrees (Al-Hadith). Based on the Hadith, the level of prayers in the congregation that were performed during the Covid-19 pandemic in the Ramadhan can be calculated. In one day, Muslim do five times of obligatory prayers, the degree of prayers that is performed is $5 \times 27$ degrees $=135$ degrees. In one month, the total degrees of prayer are $30 \times 135$ degrees= 4,050 degrees.

Ramadhan is a month full of mercy. The last ten days of Ramadhan are nights that are greatly awaited by Muslims. One of the nights in the last ten days in Ramadhan is a special night as Allah declares "The Night of Decree is better than a thousand months" (QS Al Qadr: 3). Each worship performed in the night of glory is called lailatur qadar, where all worships done will be equalized with worships for 1000 months, which is the same as 83.3 years. It is a very high degree of worship in the night of glory.

2. The implementation of sunnah Syuruq prayers

Syuruq prayer is a two rakaah prayer which is performed about twenty minutes after sunrises. Before conducting syuruq prayer, the doer should pray Fajr in the mosque and do dzikir in the mosque. Allah SWT 
promises to the doers that syuruq prayer is equivalent to doing Hajj and Umrah (Muheramtohadi, 2019). It is related to a Hadith narrated by Tirmidzi that "Whoever prays Fajr in a congregation then sits remembering Allaah until the sun rises, then prays two rak'ahs, will have a reward like that of Hajj and Umrah, Muhammad PBUH said, "Complete, complete, complete." Mathematically, the costs spent on Haj including preparation pilgrimage payment and for the celebration are about the US \$3335. If syuruq prayer it is conducted in Ramadhan, the reward is equivalent to 30 times of performing Hajj and Umrah and the value is nominally $30 \times$ US $\$ 3335=$ US $\$ 100,050$. During the Covid-19 pandemic period, families may perform prayers in congregation, including Fajr prayer, and together wait for the sun rises and also read dzikir and do syuruq prayers. Therefore, it can be stated that a family who performs syuruq prayer is equivalent to 30 times of Hajj prayer for the family.

3. Reading Al Qur'an

It is a habit that reading Al Qur'an in Ramadhan is like an obligation. During the Covid-19 pandemic period, Muslims usually read one juz or chapter of holy Quran after Taraweeh prayer and another one juz after Fajr prayer while waiting for Syuruq. It can conclude that one has finished reading Al Qur'an twice a month. As a result, it can be calculated that Muslims obtained the goodness for twice because they have finished reading Al Qur'an twice. The Messenger of Allah said that: "[Whoever recites a letter] from Allah's Book, then he receives the reward from it, and the reward of ten the like of it. I do not say that Alif Lam Mim is a letter, but Alif is a letter, Lam is a letter and Mim is a letter (Hadith narrated by Tirmidhi). It should be known that the number of letters in $\mathrm{Al}$ Qur'an is 1,027,000 letters. If one may finish reading it twice it means that the benefit obtained is $2 \times 1,027,000 \times 10=$ $20,054,000$. It means that $20,054,000$ benefits will be obtained and it is carried together with all members of the family, and each will get the benefits.

4. Charity

a. Giving foods to someone who breaks his fast

Spirits of Muslims to give charity in Ramadhan are high, especially in giving foods for breaking fasting in the Covid-19 Pandemic period, since there are a lot of people who have difficulties in getting foods for breaking their fasting. But, a hadith from the Messenger of Allah said that: "Whoever gives iftaar to one who is fasting will have a reward like his, without that detracting from the fasting person's reward in the slightest" (Narrated by Tirmidhi). During Covid-19 pandemic period, a muslim who gives some foods for breaking fasting to one person a day, he will get two rewards from the person. Since the number of days in of Ramadhan is 30 , it means that he will get rewards from 60 persons. Mathematically, the rewards obtained are multiplied, and the multiplication depends on how many fasting people are given foods for breaking their fasting.

b. Charity to people who get impacts from the Covid-19 Pandemic

There are many people without incomes during Covid-19 Pandemic. As a form of humanity action, many people share their charity by assisting others (Schlossarek, 2017). Various types of assistance are provided. Allah will replace those who are giving others 
with 700 times, as stated by Allah as follows: The example of those who spend their wealth in the way of Allah is like a seed [of grain] which grows seven spikes; in each spike is a hundred grains. And Allah multiplies [His reward] for whom He wills. And Allah is all-Encompassing and Knowing. (QS. 2: 261).

If one may give $n$ for charity every day, Allah will replace the charity with the amount of $700 \times n=$ $700 n$ to him. If in a month routinely he spends charity of $n$ each day, Allah will give reward $30 \times 700 \times n=21000 n$, $n=$ charity

The results of this study show that if it is counted mathematically, the worship in form of sunnah or compulsory conducted in Ramadhan during Covid-19 Pandemic provides many rewards.

\section{CONCLUSION AND SUGGESTION}

Covid-19 pandemic period makes all people carries out their activities such as working, learning, praying at home. Prayers performed by Muslims at home which are scientifically studied possess a great superiority if they are viewed from the rewards received. Based on mathematical analysis, it can be stated that the advantages and superiorities of worships performed during Ramadhan are as follows: 1) implementation of health protocols in carrying out worship does not reduce the meaning and reward; 2) compulsory and sunnah worship carried out during Ramadhan and Covid19 pandemic have a very high value in terms of the reward that will be given by Allah; 3) the implementation of worship during Ramadhan and the Covid-19 pandemic period provided more opportunities for Muslims to be more diligent in the implementation, and 4) the benefits and rewards obtained from the mathematical calculations can motivate Muslims to do some good deeds and Allah will only see human's deeds based on their motivation.

Based on the results of this research, the authors provide some suggestions: 1) Muslims should be istiqomah or consistent in carrying out worship, especially in Ramadhan, 2) Maintaining health protocols is still necessary and does not reduce the meaning of worship.

\section{REFERENCES}

Al-Qur'an.

Al Hadith.

Ali \& Khakwani, (2019). Eradication of Poverty through Existing Zakat System in Pakistan: An ARDL Modelling Approach to Cointegration, Pakistan Journal of Islamic Research Vol: 20, Issue: 1

Alsharidah, A., Murtaza, G., M. Alsharidah, M., \& Bashir, S. (2016). Fasting in Ramadan Affects Cognitive and Physiological Function in Normal Subjects (Pilot Study). Neuroscience and Medicine, $\quad$ 07(02). https://doi.org/10.4236/nm.2016.72 007

Cohen, J., \& Kupferschmidt, K. (2020). Strategies shift as coronavirus pandemic looms. Science, 367(6481). https://doi.org/10.1126/science.367. 6481.962

Kong, H. (2020). Considerations for school closure. Centers for Disease Control and Prevention.

Lane, I., Mullen, M., \& Logan, D. (2020). Working from Home During the COVID-19 Pandemic: Tips and Strategies to Maintain Productivity \& Connectedness. Psychiatry Information in Brief, 17(5). https://doi.org/10.7191/pib.1145 
DOI: https://doi.org/10.24127/ajpm.v9i4.3065

Muheramtohadi S (2019) The use of Hajj fund for investment purpose: amaqashid sharia approach journal of Islamic Economics, Management, and Business-Vol. 1 No. 1 119-136

Purwatiningsih, A P., \& Hermawan Adinugraha, H. (2018). Histori Filantropi: Tinjauan Teori Postmodern. ZISWAF: Jurnal Zakat Dan Wakaf, 5(1). https://doi.org/10.21043/ziswaf.v5i 1.3573

Rokhim, R., \& Octaviani, I. (2019). Is there a Ramadhan effect on Sharia mutual funds? Evidence from Indonesia and Malaysia. International Journal of Islamic and Middle Eastern Finance and Management, 13(1). https://doi.org/10.1108/IMEFM-042019-0147

Saripudin, U. (2016). Filantropi islam dan pemberdayaan ekonomi. Bisnis: Jurnal Bisnis Dan Manajemen Islam, 4(2). https://doi.org/10.21043/bisnis.v4i2 .2697

Schlossarek, M (2017)The Relevance and Meaning of Charity in the Context of Microfinance, : Development, Environment and Foresight Vol 3 No 2

Suyanto, S. (2018). Membangun Kesadaran Sodaqoh Sampah Sebagai Model Pemberdayaan Masyarakat. Jurnal Pemberdayaan Masyarakat: Media Pemikiran Dan Dakwah Pembangunan, 1(2). https://doi.org/10.14421/jpm.2017.0 12-02
Tumiran, M. A. Bin. (2018). Rangsangan Auditori Menggunakan Surah Al-Quran Kesan Terapi Praktikal Ibadah Ramadhan Dan Rangsangan Auditori Menggunakan Surah Al-Quran Terpilih Terhadap Gangguan Tidur Kanak-Kanak Autistik. Tesis.

Wasila, S., \& Shonhadji, N. (2014). A study on the zakat and infaq or sodaqoh accounting application under SFAS 109 in Al-Falah Social Fund Foundation (YDSF) Surabaya. The Indonesian Accounting Review, 4(02). https://doi.org/10.14414/tiar.v4i02. 332

Zaharah, Z., \& Kirilova, G. I. (2020). Impact of Corona Virus Outbreak Towards Teaching and Learning Activities in Indonesia. SALAM: Jurnal Sosial Dan Budaya Syar-I, 7(3).

https://doi.org/10.15408/sjsbs.v7i3. 15104 